\title{
Weed Management Practices for Organic Production of Trailing Blackberry: I. Plant Growth and Early Fruit Production
}

\author{
Renee H. Harkins ${ }^{1}$ and Bernadine C. Strik ${ }^{2,3}$ \\ Department of Horticulture, Oregon State University, 4017 ALS, Corvallis, \\ OR 97331
}

\author{
David R. Bryla \\ U.S. Department of Agriculture, Agricultural Research Service, Horticultural \\ Crop Research Unit, 3420 NW Orchard Avenue, Corvallis, OR 97330
}

Additional index words. drip irrigation, fruit quality, landscape fabric, leaf water potential, Rubus, weed mat, yield

\begin{abstract}
Weed management practices were evaluated in a new field of trailing blackberry (Rubus L. subgenus Rubus Watson) established in western Oregon. The field was planted in May 2010 and certified organic in May 2012. Treatments included two cultivars, Marion and Black Diamond, grown in 1) non-weeded plots, where weeds were cut to the ground just before harvest; 2 ) hand-weeded plots, hoed two to three times per year; and 3) weed mat plots, covered with black landscape fabric. Each treatment was fertilized with fish emulsion and irrigated by drip. Weeds increased from 2010 through 2012 in both non-weeded and hand-weeded plots and required 38 and $90 \mathrm{~h} \cdot \mathrm{ha}^{-1}$ of labor to remove the weeds in the latter treatment in 2011 and 2012, respectively. Weeds in weed mat plots, in comparison, were confined primarily to the planting holes in the fabric and required only $1 \mathrm{~h} \cdot \mathrm{ha}^{-1}$ of labor for weed removal each year. Blackberry growth, in terms of number and dry weight of the primocanes, was similar among treatments during the first year after planting but differed with cultivar and weed management the next season. In 2011, 'Black Diamond' produced shorter but an average of three more primocanes per plant than 'Marion', whereas plants in hand-weeded and weed mat plots produced nearly twice as many primocanes as non-weeded plots. Hence, when fruit were produced on floricanes (the previous year's primocanes) for the first time in 2012, 'Black Diamond' had $15 \%$ more yield than 'Marion', and weed control increased yield by $67 \%$ with handweeding and $100 \%$ with weed mat, on average. 'Black Diamond' and weed control also produced larger berries (measured as average individual fruit weight) with a greater water content but a lower soluble solids concentration. So far, of the three practices studied, weed mat was best suited to organic production of blackberries. The initial cost of the weed mat was far less than the cost of hand-weeding during the first 3 years after planting, and after only one season of fruit production, the yield benefit of weed mat provided enough profit to warrant its use over no weeding or hand-weeding.
\end{abstract}

Commercial production of blackberries (Rubus L. subgenus Rubus, Watson) has increased rapidly in recent years from a total of 13,960 ha worldwide in 1995 to 20,035 ha in 2005 (Strik et al., 2007). Approximately 6000 ha are currently produced in the United States (U.S. Department of Agriculture, 2010a). More than half of the U.S. total is processed fruit (individually quick frozen, bulk frozen,

\footnotetext{
Received for publication 7 June 2013. Accepted for publication 27 July 2013.

We thank Gil Buller, Emily Vollmer, and Amber Shireman for technical assistance and acknowledge financial support from the USDA National Institute of Food and Agriculture (Formula Grant no. OREI 2010-01940; ORE00409), the Northwest Center for Small Fruits Research, and our industry contributors. ${ }^{1}$ Graduate Student.

${ }^{2}$ Professor.

${ }^{3}$ To whom reprint requests should be addressed; e-mail strikb@hort.oregonstate.edu.
}

puree, freeze-dried, canned, juice, and juice concentrate) produced primarily in Oregon and Washington (Strik et al., 2007). Organic production has also increased to greater than 2500 ha worldwide, but there was only 200 ha in the United States in 2008 (Strik and Finn, 2012; U.S. Department of Agriculture, 2010b). However, significant expansion in organic plantings is expected in the next 10 years as consumer demand for organic products increases and growers become more interested in targeting higher-value niche markets (Strik and Finn, 2012).

Guidelines for organic blackberry production are limited at the moment. General information is available for erect and semierect types used for fresh market production (Kuepper et al., 2003), but most of it is anecdotal and does not necessarily apply to organic production of trailing types used for production of processed fruit. Trailing blackberries ripen in midsummer in Oregon and
Washington and are usually machine-harvested (Strik and Finn, 2012).

Weed management is considered critical for good production in berry crops (Barney et al., 2007; Bushway et al., 2008; Heiberg, 2002; Krewer et al., 2009; Pritts and Kelly, 2001; Zebarth et al., 1993). Blackberry plants are relatively vigorous, however, and therefore may tolerate more competition from weeds. A few commercial operations grow organic blackberries with no weed control and achieve reasonable yields (Strik, personal observations). The strategy is considered a holistic approach to weed managementmaintaining good soil properties, providing a habitat for beneficial insects, and favoring healthy crop growth and high yield (Buhler, 2002; Marshall et al., 2003; Swanton and Weise, 1991) - but weeds left uncontrolled may interfere with machine harvest and produce seeds that become fruit contaminants.

Pre-emergent and contact herbicides are commonly used in conventional blackberry plantings (Barney et al., 2007; Bushway et al., 2008), but chemical options are limited for organic production. Perforated landscape fabric, often referred to as weed mat, is an alternative option and has been approved for use as a weed barrier in organic plantings (U.S. Department of Agriculture, 2011). Trailing blackberry may be well suited to weed mat because, unlike erect and semierect types, new canes, referred to as primocanes, emerge only from the crown or the base of the plants. Weed mat is currently used with success in other perennial cropping systems, including conventional and organic tree fruit orchards (Granatstein and Mullinix, 2008) and blueberry (Vaccinium corymbosum L.) fields (Julian et al., 2012).

The use of drip irrigation may also help reduce weed problems because, unlike sprinkler systems, water is delivered in small, focused areas along the row, reducing unwanted seed germination. Many organic growers irrigate by drip for this reason and often use it in combination with weed mat. Drip may also reduce disease problems compared with overhead irrigation by allowing leaves, flowers, and fruit to stay dry after each water application. Fertilizers are easily injected through a drip system, although information on injection of organic fertilizers is limited. Schwankl and McGourty (1992) tested two organic fertilizers, spray-dried fish protein and spray-dried poultry protein, and found that both products could be injected through microsprinkler, drip, and drip-tape irrigation systems with minimal clogging.

The objective of the present study was to evaluate the effects of three different organic weed management strategies, including weed mat, hand-weeding, and no weeding, on growth and early production of trailing blackberry. Plants in each treatment were irrigated by drip and fertilized using certified organic liquid fish products. Two popular cultivars, Marion and Black Diamond, were included in the study. Both are predominantly harvested by machine for high-value processed markets and together account for greater than $75 \%$ of 
the 2914 ha of blackberries produced in Oregon in 2012 (U.S. Department of Agriculture, 2013). Like all trailing types, the cultivars are perennial but the shoots are biennial, producing primocanes the first year, which then become floricanes with flowers and fruit the next year and then senesce after harvest. Mature plants will have both primocanes and floricanes in the same year in a typical annual or every-year production system (Julian et al., 2009; Strik and Finn, 2012).

\section{Materials and Methods}

Study site. The study was conducted at the North Willamette Research and Extension Center in Aurora, OR (long. 45 ${ }^{\circ} 17^{\prime} \mathrm{N}$, lat. $122^{\circ} 45^{\prime} \mathrm{W}$; USDA hardiness zone 8 ; elevation $46 \mathrm{~m}$ ). Winter wheat (Triticum sp.) was planted at the site for at least 10 years before the study. The soil is mapped as a Willamette silt loam (fine-silty, mixed, superactive mesic Pachic Ultic Argixeroll). It was sampled for analysis on 7 Aug. 2009 and had a soil pH of 5.3 and contained $3.6 \%$ organic matter, 1.5 ppm $\mathrm{NO}_{3}-\mathrm{N}, 2.3$ ppm $\mathrm{NH}_{4}-\mathrm{N}, 188$ ppm phosphorus, and $295 \mathrm{ppm}$ potassium in the top $0.2 \mathrm{~m}$ of the soil profile (Brookside Laboratories, Inc., New Bremen, OH). The site was certified organic by an organic certifying agency in Oregon (Oregon Tilth, Salem, OR) in May 2012; although organically approved practices were followed during establishment, organic certification was not sought until the first fruit harvest year.

Site preparation. Cereal rye (Secale cereal L.) and common vetch (Vicia sativa L.) were seeded at the site on 18 May 2009 at a rate of 34 and $67 \mathrm{~kg} \cdot \mathrm{ha}^{-1}$, respectively, and incorporated on 27 Aug. 2009 using a power spader (Model 165, Series 205; Tortella, Ortona, Italy) and rototiller (Model TB 180; TerraAnova, Padova, Italy). Plant rows were marked $3.0 \mathrm{~m}$ apart (north-south direction) on 31 Aug. 2009 and sub-soiled $0.4 \mathrm{~m}$ deep using a two-shank ripper (Rankin Model R360, Yakima, WA). Lime [calcium carbonate $\left(2242 \mathrm{~kg} \cdot \mathrm{ha}^{-1}\right)$ and pelletized dolomite lime $\left.\left(4148 \mathrm{~kg} \cdot \mathrm{ha}^{-1}\right)\right]$ and fertilizer $\left[561 \mathrm{~kg} \cdot \mathrm{ha}^{-1} \mathrm{~K}\right.$ Mag (0N-0P-22K-11Mg-22S), $10 \mathrm{~kg} \cdot \mathrm{ha}^{-1}$ sulfur as granular elemental sulfur, $2 \mathrm{~kg} \cdot \mathrm{ha}^{-1}$ boron as $15 \%$ granular boron, $1 \mathrm{~kg} \cdot \mathrm{ha}^{-1} \mathrm{cop}$ per as copper sulfate, and $14 \mathrm{~kg} \cdot \mathrm{ha}^{-1}$ zinc as zinc sulfate] were then broadcast and incorporated using the power spader and rototiller. Lime was applied because the pre-existing soil $\mathrm{pH}$ in 2009 was below sufficiency for good blackberry growth (Hart et al., 2006). Cereal rye was seeded within rows and hardfine fescue (Festuca longifolia Thuill. 'Aurora Gold') was seeded between rows at a rate of $112 \mathrm{~kg} \cdot \mathrm{ha}^{-1}$ each on 7 Oct. 2009. The rye was flail mowed on 8 May 2010, and rows were sub-soiled ( $0.4 \mathrm{~m}$ deep) using a single-shank ripper and tilled using a $0.3-\mathrm{m}$ wide strip tiller.

Experimental design. The study was planted on 26 May 2010. Treatments were arranged as a split-split-split plot design with five replicates and included a row of 'Marion' and a row of 'Black Diamond' blackberry as main plots, two irrigation strategies (postharvest and no postharvest irrigation) as subplots, and a combination of three weed management strategies (weed mat, hand-hoeing, and no weeding) and two primocane training dates (August and February) as sub-subplots. Each sub-subplot consisted of four plants spaced $1.5 \mathrm{~m}$ apart inrow and was separated from plants in adjacent plots by $3.0 \mathrm{~m}$ (to provide space for clearing the machine harvester). Between-row spacing was $3.0 \mathrm{~m}$ (2222 plants/ha). The planting also had a plot of four border plants at the end of each row and a border row on each side. Overall, there were 12 rows of $104 \mathrm{~m}$ each ( $0.4 \mathrm{ha}$ ) and a total of 120 treatment plots. Because irrigation and training treatments were not initiated until Aug. 2012 (Year 3), only cultivar and weed management treatments assigned to postharvest irrigation and August training (30 plots in total) were measured during the first 2 years after planting and are therefore included in the present study.

A 1.4-m wide strip of black landscape fabric (water flow rate $6.8 \mathrm{~L} \cdot \mathrm{h} \cdot \mathrm{m}^{-2} ; 0.11$ $\mathrm{kg} \cdot \mathrm{m}^{-2}$; TenCate Protective Fabrics; OBC Northwest, Inc. Canby, OR) was centered on the row of each weed mat plot and secured in place using 0.1-m long nails. Square openings $(\approx 0.2 \mathrm{~m} \times 0.2 \mathrm{~m})$ were cut in the fabric for each plant. Cost of the weed mat was estimated at $\$ 366 / \mathrm{ha} /$ year, amortized over an expected 5-year life, with an additional \$741 and \$494/ha for installation and cutting holes for planting, respectively.

Plants propagated from tissue culture were obtained from a commercial nursery as plugs and were planted in each treatment plot along with the rooted potting media. Twelve plants died after planting and were replaced with new plugs at $60 \mathrm{~d}$ after planting. All but one dead plant were 'Marion'; five were in weed mat plots and seven were in hand-weeded plots. To encourage growth, weeds were removed by hand around each plant during the first year after planting, including those near plants $(\approx 0.2 \mathrm{~m}$ diameter $)$ in non-weeded plots.

Plants were trained on a two-wire vertical trellis in each row installed before planting. The lower trellis wire was attached to steel posts at $1.0 \mathrm{~m}$ above the ground, and the upper wire was attached at $1.6 \mathrm{~m}$. The posts were located between each plot and directly in the center of the row. Primocanes were tied to the trellis as they grew during first 2 years after planting, using bailing twine, but were cut to the crown and removed in February after the first season to increase growth and improve vigor the next year (standard commercial practice). Once the primocanes grew above the upper trellis wire in the second year, half of the canes were looped in one direction down to the lower trellis wire and brought back toward the plant with one or two twists, and the other half was looped in the opposite direction (Strik and Finn, 2012). By Year 3, plants had both primocanes and floricanes (the previous year's primocanes). At this point, new primocanes were tied to the lowest trellis wire, underneath the floricane canopy, and, depending on the training date treatment, were tied to the trellis in either August or February.

Irrigation and fertilizer applications. Irrigation was applied using a single lateral of drip tubing (UNIRAM; Netafim USA, Fresno, CA) installed in each treatment plot immediately after planting. The tubing had $1.9 \mathrm{~L} \cdot \mathrm{h}^{-1}$ in-line, pressure-compensating emitters spaced every $0.6 \mathrm{~m}$ and was placed under the landscape fabric, at the base of the plants, in weed mat plots and was attached to a third wire on the steel posts, located $0.3 \mathrm{~m}$ above the ground, in hand-weeded and non-weeded plots. Each weed management treatment was irrigated independently using a manifold with electric solenoid valves and an automatic timer.

Irrigation was scheduled weekly based on estimates of crop evapotranspiration (ET) but adjusted as needed each week to maintain similar leaf water potentials among treatments. Crop ET was calculated by multiplying reference ET by a crop coefficient for caneberry that was downloaded daily along with weather data, including air temperature and precipitation, obtained from a Pacific Northwest Cooperative Agricultural Weather Network AgriMet weather station (http://usbr. gov/pn/agrimet/). The weather station was located in a field of tall fescue [Lolium arundinacea (Schreb.) S.J. Darbyshire] $\approx 0.5 \mathrm{~km}$ from the site. Leaf water potential was measured weekly after irrigation was initiated, beginning the second week after planting, using a pressure chamber (Model 1000; PMS Equipment, Albany, OR). The measurements were made between 1100 and $1330 \mathrm{HR}$ on one recent fully expanded primocane leaf in three replicate plots per treatment. Irrigation was increased by $10 \%$ above the previous week's rate when mean weekly water potential in a given weed management treatment was lower than the mean of any other weed management treatment in the cultivar. Water applications were measured in each treatment using turbine water meters (Model 36M201T; Netafim USA, Fresno, CA) installed in the irrigation manifold. There was no evidence of water runoff during irrigation in any treatment.

Soil water content was measured on 28 July 2010 using a Trase I time domain reflectometry (TDR) system (Soilmoisture Equipment Corp., Santa Barbara, CA) to determine the distribution of water between drip emitters after irrigation and to ensure that soil moisture was adequate (greater than $20 \%$ ) near the young plants. The TDR system was equipped with a pair of $0.15-\mathrm{m}$ stainless steel waveguides and a waveguide connector. The waveguides were installed vertically - in the middle of the row, at each $0.1 \mathrm{~m}$ location between two plants - in five hand-weeded 'Marion' plots.

Plants were fertilized using Organic Materials Review Institute-approved pelletized, processed poultry litter $(4 \mathrm{~N}-3 \mathrm{P}-2 \mathrm{~K}-7 \mathrm{Ca}$; Nutri-Rich; Stutzman Environmental Products Inc., Canby, OR) and Fish Agra (4N$1 \mathrm{P}-1 \mathrm{~K}$; Northeast Organics, Manchester-bythe-Sea, MA) in 2010 and TRUE 402 liquid fertilizer $(4 \mathrm{~N}-0 \mathrm{P}-2 \mathrm{~K}$; True Organic Products, Inc., Spreckels, CA) in 2011 and 2012. The Nutri-Rich was incorporated into the soil $\left(\approx 0.45 \mathrm{~m}\right.$ diameter) at a rate of $28 \mathrm{~kg} \cdot \mathrm{ha}^{-1}$ nitrogen $(\mathrm{N})$ just before planting. Fish Agra was diluted with 10 parts water $(\mathrm{v} / \mathrm{v})$ and 
applied by hand, around the base of plants, in seven weekly applications of $4 \mathrm{~kg} \cdot \mathrm{ha}^{-1} \mathrm{~N}$ each from 14 July to 25 Aug. 2010 (28 $\mathrm{kg} \cdot \mathrm{ha}^{-1}$ total N). TRUE 402 was also diluted with 10 parts water but applied by fertigation (injection through the drip system) using a Mix-Rite TF10-002 fertilizer injector (DEMA, St. Louis, MO). Irrigation was run for $10 \mathrm{~min}$ before each injection to fully pressurize the system and was also run for an additional hour afterward to flush the drip lines. In 2011, plants were fertigated with $8.0 \mathrm{~kg} \cdot \mathrm{ha}^{-1} \mathrm{~N}$ on 15 Apr. and then $16 \mathrm{~kg} \cdot \mathrm{ha}^{-1} \mathrm{~N}$ each on 9 May and 1 and 20 June $\left(56 \mathrm{~kg} \cdot \mathrm{ha}^{-1}\right.$ total $\left.\mathrm{N}\right)$. In $2012,14 \mathrm{~kg} \cdot \mathrm{ha}^{-1} \mathrm{~N}$ was fertigated on each of the following dates: 23 Apr., 8 May, and 7 and 13 June $\left(56 \mathrm{~kg} \cdot \mathrm{ha}^{-1}\right.$ total N).

Weed management. Weeds were hoed from hand-weeded plots and pulled from weed mat plots on $20 \mathrm{Apr}$. and 8 June in 2011 and on 20 Mar., 8 May, and 25 June in 2012, and the labor required to weed each treatment was recorded. Labor was valued at $\$ 15 / \mathrm{h}$. The weeds were removed when relatively small, which is typical for commercial production. The most common weed species present in the field were identified in six nonweeded plots (three 'Marion' and three 'Black Diamond') on 20 June 2011 and 25 June 2012, and percent weed cover was estimated visually using a $1-\mathrm{m}^{2}$ grid randomly located in each plot. Weeds in the grid were cut at the soil surface on 25 July 2011 and 27 June 2012 (just before fruit harvest) and oven-dried at $70^{\circ} \mathrm{C}$ and weighed; remaining weeds were then mowed to the ground in each plot using a string trimmer.

Plant growth and fruit production. Primocanes were counted at $0.3 \mathrm{~m}$ height in each plot in Feb. 2011 and Jan. 2012 and 2013. A primocane from two plants per plot was then randomly selected and measured for length (Feb. 2011 and Jan. 2012 only), oven-dried at $70{ }^{\circ} \mathrm{C}$, and weighed to estimate primocane biomass per plant. In Jan. 2013, there was insufficient growth to destructively measure primocane biomass; thus, a regression equation of primocane number to dry weight (DW) in 2011 was used to estimate DW in
$2012\left(\mathrm{DW}_{2011}=-6.46 \mathrm{x}^{2}+178.16 \mathrm{x}-305.6\right.$; $\left.R^{2}=0.53 ; P<0.0001\right)$.

Ripe fruit were harvested twice weekly in July 2012 using an over-the-row rotary harvester (Littau Harvesters Inc., Stayton, OR). Total marketable fruit and culls (sunburned, damaged, or underripe fruit) were weighed on each harvest date, and a subsample of 25 berries was randomly selected from each plot and weighed to determine average individual fruit weight. A weighted average berry weight was calculated for the fruiting season. The subsamples were also measured for percent soluble solids on three dates (early, mid-, and late season in each cultivar) using a digital refractometer (Atago, Bellevue, WA). At midharvest, a $60-\mathrm{g}$ subsample of ripe fruit per plot was shipped overnight to Brookside Laboratories to determine percent water content.

A floricane was sampled from two plants per plot in Aug. 2012 (after harvest) and measured for length and the total number of nodes, fruiting laterals, and fruiting sites per cane. The remaining floricanes were then cut to the crown, placed between rows, and flailmowed (standard commercial practice).

Data analysis. Data were analyzed for a split-plot design using PROC GLM in SAS (SAS Institute Inc., Cary, NC), and means were separated at the 5\% level using Fisher's protected least significant difference test. As a result of variations in management, analysis of variance calculations were completed within a year and not across years.

\section{Results and Discussion}

Weather and irrigation. Weather conditions were cool and wet in the spring and warm and dry in the summer at the site, which is normal for western Oregon (Table 1). Mean daily air temperatures ranged from 5.4 to $21.1{ }^{\circ} \mathrm{C}$ in April and May and 10.8 to $29.0{ }^{\circ} \mathrm{C}$ in June through August each year. The lowest temperature in any growing season was $-1.7{ }^{\circ} \mathrm{C}$ (8 Apr. 2011) and the highest was $39.6{ }^{\circ} \mathrm{C}$ (4 Aug. 2012). Most rain occurred from October to March, when plants were dormant (Table 1).
Irrigation was needed from May or June to the end of September each year (Table 1). Water was applied frequently in the first year after planting (four 15- to 30-min applications per day with $2 \mathrm{~h}$ between applications) to ensure the young plants were well watered during establishment. Soil water content ranged from $22 \%$ to $35 \%$ between emitters (Fig. 1) and was within the limits considered available for plant water uptake in silty loam soil (Saxton and Rawls, 2006). A total of $230 \mathrm{~mm}$ of irrigation was applied in Year 1. Irrigation was increased to $367 \mathrm{~mm}$ the next year but scheduled in three to four single applications per week. By 2012, a total of 548 $\mathrm{mm}$ was applied. Once again, irrigation was scheduled three to four times per week, except in July, when it was applied daily during harvest. Water requirements are generally highest during harvest in berry crops (Bryla and Strik, 2007, 2008).

To maintain similar leaf water potentials among treatments, additional water was added to weed mat plots compared with handweeding or no weeding, particularly in 'Marion' in 2011 (Table 1, footnote "x"). Plastic mulches such as weed mat increase canopy temperatures during the day and therefore often result in more plant water use (Allen et al., 1998; Larco, 2010). The effect was probably lower in 2012 because plants were larger (shaded and more weed mat). However, it was not clear why the cultivars differed. Leaf water potential was often lower in 'Marion' than in 'Black Diamond' (eight of 12 dates in 2011 and four dates of 12 dates in 2012), but values were always greater than $-1.0 \mathrm{MPa}$ in both cultivars and only differed by $0.1 \mathrm{MPa}$ when averaged over 12 measurement dates in 2011 and 11 measurement dates in 2012 (data not shown). Water potentials were also similar among weed management treatments each year and, within a cultivar, never differed by more than $0.3 \mathrm{MPa}$.

Weeds. In non-weeded plots, the proportion of the plot covered by weeds increased from $\approx 30 \%$ in 2010 to nearly $100 \%$ in each of the next 2 years. Approximately $2 \mathrm{~h} \cdot \mathrm{ha}^{-1}$ (\$30) of labor was required to hand-pull

Table 1 . Mean daily air temperature, reference evapotranspiration (ET $\mathrm{E}_{\text {ref }}$ ), precipitation, and irrigation applied to organic blackberry plants in $2010-12{ }^{z}$

\begin{tabular}{|c|c|c|c|c|c|c|c|c|c|c|c|c|}
\hline \multirow[b]{2}{*}{ Month } & \multicolumn{3}{|c|}{ Mean daily air temp $\left({ }^{\circ} \mathrm{C}\right)$} & \multicolumn{3}{|c|}{$\mathrm{ET}_{\mathrm{ref}}(\mathrm{mm})$} & \multicolumn{3}{|c|}{ Precipitation $(\mathrm{mm})$} & \multicolumn{3}{|c|}{ Irrigation $(\mathrm{mm})^{\mathrm{y}}$} \\
\hline & 2010 & 2011 & 2012 & 2010 & 2011 & 2012 & 2010 & 2011 & 2012 & 2010 & $2011^{x}$ & $2012^{x}$ \\
\hline January & 7.7 & 5.4 & 5.1 & 21 & 15 & 17 & 163 & 129 & 223 & - & 0 & 0 \\
\hline February & 8.3 & 4.3 & 6.4 & 32 & 25 & 28 & 90 & 121 & 101 & - & 0 & 0 \\
\hline March & 8.6 & 7.7 & 7.1 & 53 & 40 & 38 & 131 & 176 & 226 & - & 0 & 0 \\
\hline April & 9.7 & 8.3 & 11.0 & 70 & 64 & 65 & 80 & 123 & 106 & - & 0 & 0 \\
\hline May & 11.9 & 11.4 & 13.5 & 89 & 85 & 106 & 125 & 88 & 78 & 6 & 0 & 19 \\
\hline June & 15.3 & 15.8 & 15.4 & 99 & 102 & 108 & 86 & 26 & 67 & 32 & 51 & 115 \\
\hline July & 19.4 & 18.4 & 19.3 & 148 & 129 & 138 & 6 & 29 & 13 & 60 & 119 & 181 \\
\hline August & 19.2 & 19.9 & 20.4 & 128 & 127 & 141 & 0 & 2 & 0 & 67 & 124 & 121 \\
\hline September & 16.9 & 18.5 & 17.6 & 72 & 90 & 93 & 55 & 19 & 3 & 65 & 73 & 112 \\
\hline October & 12.2 & 12.0 & 12.8 & 42 & 35 & 53 & 133 & 61 & 169 & 0 & 0 & 0 \\
\hline November & 7.4 & 6.5 & 8.8 & 19 & 17 & 20 & 171 & 151 & 227 & 0 & 0 & 0 \\
\hline December & 6.4 & 3.1 & 5.6 & 18 & 11 & 14 & 251 & 87 & 204 & 0 & 0 & 0 \\
\hline Total/avg & 11.9 & 10.9 & 11.9 & 790 & 739 & 821 & 1290 & 1013 & 1416 & 230 & 367 & 548 \\
\hline
\end{tabular}

${ }^{\mathrm{z}}$ Weather data were obtained from a nearby AgriMet weather station (Aurora, OR).

yrrigation was applied 26 May (planting) to 30 Sept. 2010, 13 June to 30 Sept. 2011, and 18 May to 30 Sept. 2012.

${ }^{\mathrm{x}}$ To maintain similar primocane leaf water potentials among treatments, 'Marion' plants with weed mat were irrigated with an additional 103 mm of water in July to Sept. 2011 and $21 \mathrm{~mm}$ in July to Sept. 2012, whereas 'Black Diamond' plants with weed mat were irrigated with an additional 34 mm of water in Aug. to Sept. 2011 but with no additional water in 2012. 
weeds around the blackberry plants in 2010 . Dominant weed species included Stellaria media (L.) Vill., Taraxacum officinale F.H. Wigg, Euphorbia esula L., Poa annua L., Sonchus oleraceus L., Anthemis cotula L., and Avena fatua L. Total weed biomass (aboveground) averaged $2.1 \mathrm{~kg} / \mathrm{plot}$ (DW) in Year 2 and $2.2 \mathrm{~kg} / \mathrm{plot}$ in Year 3. Weed biomass was unaffected by cultivar in either year. Weeds were mowed before harvest in 2012 and therefore did not interfere with the rotary harvester.

Weed biomass also increased in handweeded plots. A total of $9 \mathrm{~h} \cdot \mathrm{ha}^{-1}(\$ 135), 38$ $\mathrm{h} \cdot \mathrm{ha}^{-1}(\$ 570)$, and $90 \mathrm{~h} \cdot \mathrm{ha}^{-1}(\$ 1350)$ of hand labor was required to hoe the plots in 2010 through 2012, respectively. The higher labor requirements in 2012 may have been attributable, at least in part, to the high number of weed seeds produced in nearby non-weeded plots (Koocheki et al., 2009). In contrast, only $1 \mathrm{~h} \cdot \mathrm{ha}^{-1}(\$ 15)$ of labor was required per year to remove weeds from the planting hole area in weed mat plots, on average. Similar labor requirements were noted with weed mat in organic blueberry and orchard systems (Julian et al., 2012; Neilsen et al., 2003). In our study, use of weed mat increased costs by $\$ 2347$ and \$322/ha relative to non-weeded and hand-weeded systems, respectively, over the 3 years of establishment.

Primocane production. Primocanes were longer in 'Marion' than in 'Black Diamond' beginning the first year of planting but were unaffected by weed management until the next season (Table 2). By the end of 2011, the number of primocanes per plant increased in all treatments from the previous year, but 'Black Diamond' had more primocanes than 'Marion', and weed control with either weed mat or hand-weeding nearly doubled primocane production relative to non-weeded plots. The number of primocanes in 'Marion' was similar to the number produced previously by young plants grown under conventional conditions (Bell et al., 1995) but was less than the 16 to 20 primocanes produced by mature plants during an "off-year" (i.e., all floricanes removed in a given year to increase production the next year) (Cortell and Strik, 1997a). In general, 'Black Diamond' was less vigorous than 'Marion', producing shorter primocanes and less biomass aboveground, agreeing with observations reported by Finn et al. (2005). Primocane vigor (number and biomass), however, was increased by weed control in both cultivars, although interestingly the length of individual primocanes was longer in nonweeded than in weed mat plots (Table 2). Weed control also increased primocane production in red raspberry, but, in this case, had no effect on primocane length (Bowen and Freyman, 1995).

Primocane production declined when plants were harvested for the first time in 2012, and neither primocane number nor DW was affected by cultivar or weed management (Table 2). However, given the previously described differences in plant growth by cultivar in 2011, future work may expect to see a greater nutrient efficiency of 'Black Diamond' plants over 'Marion' plants during plant maturity. Cortell and Strik (1997a) also observed lower primocane production in 'Marion' when floricanes were present. Floricanes reduce light penetration into the canopy and may compete with primocanes during fruit production for carbon and nutrients (Cortell and Strik, 1997b; Mohadjer et al., 2001).

Early fruit production. 'Marion' produced longer floricanes (or longer primocanes the previous year) with more nodes and shorter internode lengths than 'Black Diamond' and therefore had greater fruit production potential per floricane (Table 3). 'Black Diamond', however, produced more floricanes/plant and more flowers/lateral than 'Marion', which, when combined with a higher average individual fruit weight, resulted in a higher total yield in 'Black Diamond' (Tables 2 and 3). 'Black Diamond' also had a longer and more consistent fruit production season than 'Marion' (Fig. 2A). Total marketable yield averaged $13.3 \mathrm{t} \cdot \mathrm{ha}^{-1}$ in 'Black Diamond' and 11.6 t.ha ${ }^{-1}$ in 'Marion', which is similar to mature conventional, machine-harvested, commercial fields in Oregon and surpassed yields expected for 'Marion' during establishment (Julian et al., 2009). In this early fruit production year, 'Black Diamond' produced an average of $\$ 3751 /$ ha greater
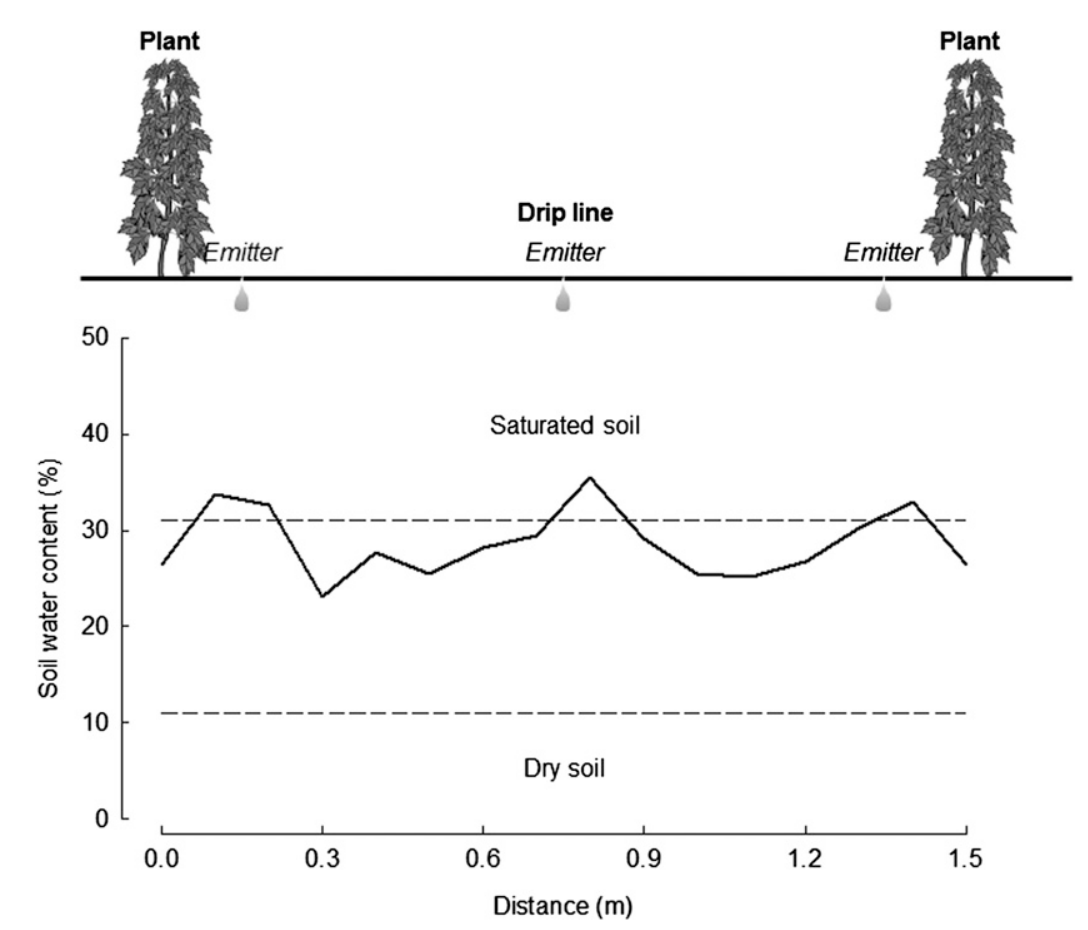

Fig. 1. Soil water content measured in the middle of the row between two hand-weeded blackberry plants. Plants were irrigated using a single lateral of drip tubing with $1.9 \mathrm{~L} \cdot \mathrm{h}^{-1}$ in-line emitters every $0.6 \mathrm{~m}$ located near the base of the plants. Measurements were taken on 28 July 2010 (Year 1) using a $0.15-\mathrm{m}$ time domain reflectometry probe, inserted vertically, at each $0.1-\mathrm{m}$ increment between the plants. The data represent the mean of four plots and have a pooled SE of $3.3 \%$. The lower dashed line represents the permanent wilting point, as defined by Saxton and Rawls (2006), and the upper dashed line represents field capacity.

Table 2. The effects of cultivar and weed management strategies on primocane growth in 'Black Diamond' and 'Marion' trailing blackberry after the first 3 years after planting (2010-12 growing seasons). ${ }^{\mathrm{z}}$

\begin{tabular}{|c|c|c|c|c|c|c|c|c|}
\hline \multirow[b]{2}{*}{ Treatment } & \multicolumn{2}{|c|}{$\begin{array}{l}\text { Avg primocane } \\
\text { length }(\mathrm{m})\end{array}$} & \multicolumn{3}{|c|}{$\begin{array}{c}\text { Primocane } \\
\text { no./plant }\end{array}$} & \multicolumn{3}{|c|}{$\begin{array}{l}\text { Primocane dry } \\
\text { wt (kg/plant) }\end{array}$} \\
\hline & 2010 & 2011 & 2010 & 2011 & 2012 & 2010 & 2011 & 2012 \\
\hline \multicolumn{9}{|l|}{ Cultivar $(C)$} \\
\hline Black Diamond & 1.8 & 3.3 & 3.4 & 11.6 & 4.2 & 0.1 & 0.8 & 0.1 \\
\hline Marion & 3.0 & 6.9 & 3.4 & 8.6 & 4.3 & 0.1 & 1.0 & 0.1 \\
\hline Significance & 0.0003 & $<0.0001$ & NS & $<0.0001$ & NS & NS & 0.05 & NS \\
\hline \multicolumn{9}{|c|}{ Weed management $(W)$} \\
\hline Non-weeded & - & $5.8 \mathrm{a}^{\mathrm{y}}$ & - & $6.5 \mathrm{~b}$ & 3.7 & - & $0.6 \mathrm{~b}$ & 0.1 \\
\hline Hand-weeded & 2.5 & $5.4 \mathrm{ab}$ & 3.4 & $11.6 \mathrm{a}$ & 4.7 & 0.1 & $1.0 \mathrm{a}$ & 0.1 \\
\hline Weed mat & 2.2 & $4.1 \mathrm{~b}$ & 3.4 & $12.2 \mathrm{a}$ & 4.3 & 0.1 & $1.1 \mathrm{a}$ & 0.1 \\
\hline Significance & NS & 0.04 & NS & $<0.0001$ & NS & NS & $<0.0001$ & NS \\
\hline \multicolumn{9}{|l|}{ Interaction } \\
\hline$C \times W$ & NS & NS & NS & NS & NS & NS & NS & NS \\
\hline
\end{tabular}

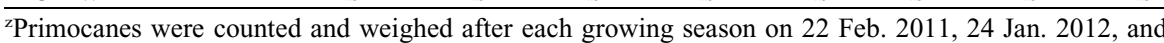
23 Jan. 2013. $\mathrm{N}=15$ for cultivar main effect means; $\mathrm{n}=10$ for weed management main effect means. ${ }^{y}$ Means followed by the same letter within a column were not significantly different at the 0.05 level. NS $=$ nonsignificant. 
Table 3. The effects of cultivar and weed management strategies on floricane traits, yield, and fruit quality in 'Black Diamond' and 'Marion' trailing blackberry during the first year of fruit production (July 2012).

\begin{tabular}{|c|c|c|c|c|c|c|c|c|c|c|}
\hline Treatment & \multicolumn{5}{|c|}{ Floricanes } & $\begin{array}{c}\text { Total } \\
\text { marketable } \\
\text { yield }(\mathrm{kg} / \mathrm{plant})\end{array}$ & $\begin{array}{c}\text { Culls } \\
\text { (g/plant) }\end{array}$ & $\begin{array}{c}\text { Avg } \\
\text { individual fruit } \\
\text { wt (g/berry) }\end{array}$ & $\begin{array}{c}\text { Fruit } \\
\text { water } \\
\text { content (\%) }\end{array}$ & $\begin{array}{c}\text { Fruit } \\
\text { soluble } \\
\text { solids (\%) }\end{array}$ \\
\hline \multicolumn{11}{|l|}{ Cultivar $(C)$} \\
\hline Black Diamond & 3.1 & 103.8 & 0.05 & 40.1 & 5.7 & 6.0 & 28.8 & 5.5 & 86.5 & 10.6 \\
\hline Significance & 0.0007 & 0.04 & 0.01 & NS & 0.002 & $<0.0001$ & $<0.0001$ & $<0.0001$ & 0.0001 & $<0.0001$ \\
\hline \multicolumn{11}{|c|}{ Weed management $(W)$} \\
\hline Non-weeded & 3.9 & 111.1 & 0.04 & 41.9 & 5.0 & $3.6 \mathrm{c}^{\mathrm{z}}$ & $29.1 \mathrm{~b}$ & $4.9 \mathrm{~b}$ & $84.3 \mathrm{~b}$ & $12.4 \mathrm{a}$ \\
\hline Significance & NS & NS & NS & NS & NS & $<0.0001$ & $<0.0001$ & $<0.0001$ & 0.02 & $<0.0001$ \\
\hline \multicolumn{11}{|l|}{ Interaction } \\
\hline$C \times W$ & NS & NS & NS & NS & NS & NS & NS & NS & NS & NS \\
\hline
\end{tabular}

${ }^{\mathrm{z}}$ Means followed by the same letter within a column were not significantly different at the 0.05 level. $\mathrm{N}=15$ for cultivar main effect means; $\mathrm{n}=10$ for weed management main effect means.

NS = nonsignificant.
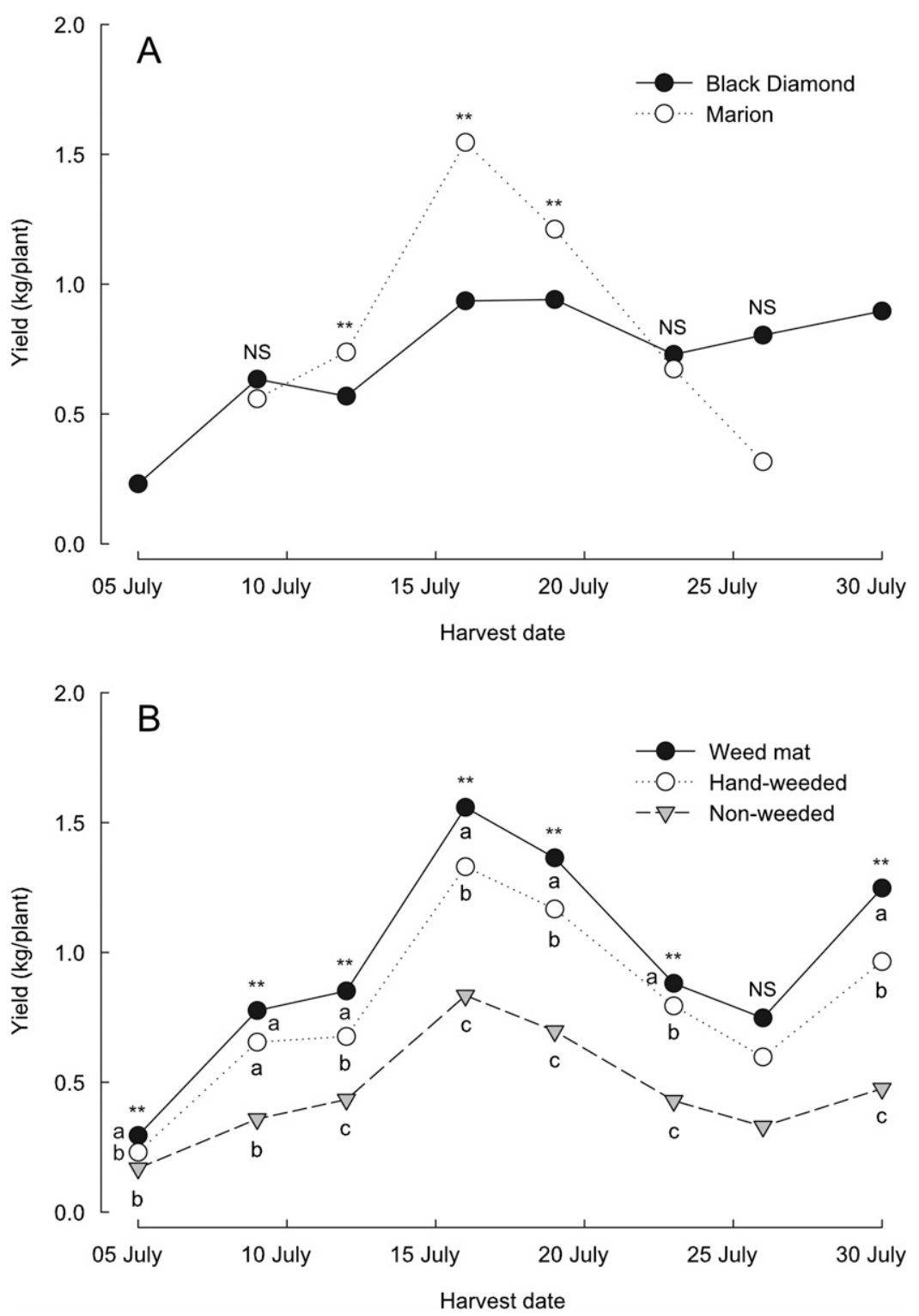

Fig. 2. Effects of cultivar (A) and weed management strategies (B) on marketable yield in 'Black Diamond' and 'Marion' trailing blackberry during the first year of fruit production in 2012. 'Black Diamond' was harvested from 5 July to 30 July, and 'Marion' was harvested from 9 July to 26 July. Each symbol represents the mean of five replicates. Weed management treatments were separated by Fisher's protected least significant difference on each date at the $5 \%$ level. Ns, ${ }^{* *}$ Nonsignificant and significant at $P \leq 0.01$, respectively. income from fruit harvest than 'Marion' (at $\$ 2.11 / \mathrm{kg}$ ).

Plants also had higher yields with weed control, particularly when weed mat was used (Table 3; Fig. 2B). Plants with weed mat produced twice as much fruit as those in nonweeded plots (added fruit income of $\$ 16,878$ / ha) but also produced $20 \%$ more fruit (added income of $\$ 5,626 / \mathrm{ha}$ ) than hand-weeded plants. Although weeds were removed with handweeding, the timing of removal may have led to weed competition in the plants (Everaarts, 1992; Van Heemst, 1985). Net income (fruit harvest minus weed management costs over the 3 years), not including other management costs which were assumed to be equivalent among weed management treatments, was $\$ 31,380 /$ ha in the weed mat, $86 \%$ and $20 \%$ greater than in the non-weeded and handweeded systems, respectively.

Weed control also increased berry weight and fruit water content but reduced percent soluble solids in the fruit (Table 3). It is not known whether increased berry weight was the result of more drupelets/fruit, higher drupelet weight, or a combination of both, and whether the reduction in soluble solids was the result of fewer solids or a dilution of the solids (Strik et al., 1996). Although primocane leaf water potentials were similar among treatments, primocanes and floricanes appear to be hydraulically independent (Bryla and Strik, 2008). Competition from weeds may have limited water more in floricanes than in primocanes and therefore resulted in less fruit water content and weight and a higher concentration of soluble solids. However, berry weight, fruit water content, and soluble solids also differed between cultivars in a similar manner (i.e., water content was higher and soluble solids were lower in 'Black Diamond' with larger fruit; Table 3), suggesting that fruit water content was not necessarily a function of plant water relations. Water measurements on floricanes and further quantification of fruit components will be determined in the treatments in later studies.

Weed management had no effect on any of the floricane traits measured, including internode number and length, percent budbreak, 
and number of flowers/lateral, and only $0.5 \%$ to $0.8 \%$ of the fruit harvested in any treatment was non-marketable (culls) (Table 3). Weeds, however, clearly reduced plant growth, fruit production, and income during the first few years after planting. Similar results were found in other fruit crops (Burkhard et al., 2009; Sanguankeo et al., 2009; Tworkoski and Glenn, 2001).

\section{Conclusions}

The results of the study indicate that weed control is beneficial during establishment of trailing blackberry and can be done successfully in organic plantings using hand-weeding or weed mat. Of the two, weed mat led to the highest yield and net returns in the study and required only $1 \mathrm{~h} \cdot \mathrm{ha}^{-1}$ of labor for weed control each year. Weeds reduced primocane number and dry weight per plant and ultimately resulted in lower yield. Weeds likely compete with the young blackberry plants for both light and soil resources, but further work is needed to determine whether floricane water status was also impacted by weeds and whether plant and soil nutrients were limited. Both 'Black Diamond' and 'Marion' appeared well suited to organic production in the present study. The study will continue for at least 3 more years to determine sustainability of each practice.

\section{Literature Cited}

Allen, R.G., L.S. Pereira, D. Raes, and M. Smith. 1998. Crop evapotranspiration. Guidelines for computing crop water requirements. FAO Irrigation and Drainage Paper 56. Food and Agriculture Organization of the United Nations, Rome, Italy.

Barney, D.L., P. Bristow, C Cogger, S.M. Fitzpatrick, J. Hart, D. Kaufman, C. Miles, T. Miller, P.P. Moore, T. Murray, H. Rempel, B. Strik, and L. Tanigoshi. 2007. Commercial red raspberry production in the Pacific Northwest. Pacific Northwest Ext. Publ. PNW 598.

Bell, N.C., B.C. Strik, and L.W. Martin. 1995. Effect of primocane suppression date on Marion trailing blackberry. 1. Yield components. J. Amer. Soc. Hort. Sci. 120:21-24.

Bowen, P. and S. Freyman. 1995. Ground covers affect raspberry yield, photosynthesis, and nitrogen nutrition of primocanes. HortScience 30:238-241.

Bryla, D.R. and B.C. Strik. 2007. Effects of cultivar and plant spacing on the seasonal water requirements of highbush blueberry. J. Amer. Soc. Hort. Sci. 132:270-277.

Bryla, D.R. and B.C. Strik. 2008. Do primocanes and floricanes compete for soil water in blackberry? Acta Hort. 777:477-482.

Buhler, D.D. 2002. Challenges and opportunities for integrated weed management. Weed Sci. 50:273-280.
Burkhard, N., D. Lynch, D. Percival, and M. Sharifi. 2009. Organic mulch impact on vegetation dynamics and productivity of highbush blueberry under organic production. HortScience 44:688-696.

Bushway, L., M. Pritts, and D. Handley. 2008. Raspberry and blackberry production guide for the Northeast, Midwest, and eastern Canada. Natural Resources Agr. Eng. Serv., Coop. Ext., Ithaca, NY.

Cortell, J.M. and B.C. Strik. 1997a. Effect of floricane number in 'Marion' trailing blackberry. I. Primocane growth and cold hardiness. J. Amer. Soc. Hort. Sci. 122:604-610.

Cortell, J.M. and B.C. Strik. 1997b. Effect of floricane number in 'Marion' trailing blackberry. II. Yield components and dry mass partitioning. J. Amer. Soc. Hort. Sci. 122: 611-615.

Everaarts, A.P. 1992. Effects of competition with weeds on growth, development and yield of soybeans. Neth. J. Agr. Sci. 40:91-107.

Finn, C.E., B.M. Yorgey, B.C. Strik, H.K. Hall, R.R. Martin, and M. Qian. 2005. 'Black Diamond' thornless trailing blackberry. HortScience 40: 2175-2178.

Granatstein, D. and K. Mullinix. 2008. Mulching options for Northwest organic and conventional orchards. HortScience 43:45-50.

Hart, J., B. Strik, and H. Rempel. 2006. Caneberries. Nutrient management guide. Ore. State Univ. Ext. Serv., EM 8903-E.

Heiberg, N. 2002. Effect of vegetation control and nitrogen fertilization in red raspberry. Acta Hort. 585:579-583.

Julian, J., C. Seavert, B. Strik, and D. Kaufman. 2009. Berry economics: Establishing and producing 'Marion' blackberries in the Willamette Valley, Oregon. Ore. St. Univ. Ext. Serv. EM 8773-revised.

Julian, J.W., B.C. Strik, H.O. Larco, D.R. Bryla, and D.M. Sullivan. 2012. Costs of establishing organic northern highbush blueberry: Impacts of planting method, fertilization, and mulch type. HortScience 47:866-873.

Koocheki, A., M. Nassiri, L. Alimoradi, and R. Ghorbani. 2009. Effect of cropping systems and crop rotations on weeds. Agron. Sustainable Dev. 29:401-408.

Krewer, G., M. Tertuliano, P. Andersen, O. Liburd, G. Fonsah, H. Serri, and B. Mullinix. 2009. Effect of mulches on the establishment of organically grown blueberries in Georgia. Acta Hort. 810:483-488.

Kuepper, G.L., H. Born, and J. Bachmann. 2003. Organic culture of bramble fruits. Horticultural production guide. Appropriate Technol. Transfer Rural Areas, IP022. 5 Feb. 2013. <http:// attra.ncat.org/attra-pub/bramble.html $>$.

Larco, H.O. 2010. Effect of planting method, weed management, and fertilizer on plant growth and yield of newly established organic highbush blueberries. MS thesis, Ore. St. Univ., Corvallis, OR. $<$ http://ir.library.oregonstate.edu/xmlui/ handle/1957/18065>.

Marshall, E.J.P., V.K. Brown, N.D. Boatman, P.J.W. Lutman, G.R. Squire, and L.K. Ward. 2003. The role of weeds in supporting biological diversity within crop fields. Weed Res. 43: 77-89.

Mohadjer, P., B.C. Strik, B.J. Zebarth, and T.L. Righetti. 2001. Nitrogen uptake, partitioning and remobilization in 'Kotata' blackberry in alternate-year production. J. Hort. Sci. Biotechnol. 76:700-708.

Neilsen, G.H., E.J. Houge, T. Forge, and D. Neilsen. 2003. Mulches and biosolids affect vigor, yield, and leaf nutrition of fertigated high density apple. HortScience 38:41-45.

Pritts, M.P. and M.J. Kelly. 2001. Early season weed competition reduces yield of newly planted matted row strawberries. HortScience 36:729-731.

Sanguankeo, P.P., R.G. Leon, and J. Malone. 2009. Impact of weed management practices on grapevine growth and yield components. Weed Sci. 57:103-107.

Saxton, K.E. and W.J. Rawls. 2006. Soil water characteristic estimates by texture and organic matter for hydrologic solutions. Soil Sci. Soc. Amer. J. 70:1569-1578.

Schwankl, L.J. and G. McGourty. 1992. Beforeand-after tests on emitters show organic fertilizers can be injected through low-volume irrigation systems. Calif. Agr. 46:21-23.

Strik, B., J. Mann, and C. Finn. 1996. Percent drupelet set varies among blackberry genotypes. J. Amer. Soc. Hort. Sci. 121:371-373.

Strik, B.C., J.R. Clark, C.E. Finn, and M.P. Bañados. 2007. Worldwide blackberry production. HortTechnology 17:205-213.

Strik, B.C. and C. Finn. 2012. Blackberry production systems - A worldwide perspective. Acta Hort. 946:341-348.

Swanton, C.J. and S.F. Weise. 1991. Integrated weed management-The rationale and approach. Weed Technol. 5:657-663.

Tworkoski, T.J. and D.M. Glenn. 2001. Yield, shoot and root growth, and physiological responses of mature peach trees to grass competition. HortScience 36:1214-1218.

U.S. Department of Agriculture. 2010a. Oregon berries. U.S. Dept. Agr., Natl. Agr. Statistical Serv., Washington, DC.

U.S. Department of Agriculture. 2010b. 2007 Census of agriculture. Organic production survey (2008), vol. 3, spec. studies, part 2. U.S. Dept. Agr., Natl. Agr. Statistical Serv., Washington, DC.

U.S. Department of Agriculture. 2011. The program handbook: Guidance and instructions for accredited certifying agents and certified operations. U.S. Dept. Agr., Agr. Marketing Serv., Natl. Organic Program, Washington, DC.

U.S. Department of Agriculture. 2013. Berry release. Washington and Oregon berry crops: Acres, yield, production, price, and value, 2010-2012. U.S. Dept. Agr., Natl. Agr. Statistical Serv., Washington, DC.

Van Heemst, H.D.J. 1985. The influence of weed competition on crop yield. Agric. Syst. 18:81-93.

Zebarth, B.J., S. Freyman, and C.G. Kowalenko. 1993. Effect of ground covers and tillage between raspberry rows on selected soil physical and chemical parameters and crop response. Can. J. Soil Sci. 73:481-488. 